\title{
Does Household of India Face Out of Pocket Expenditure?
}

\section{Dhasarathi Kumar}

Department of Public Health, SRM University, Chennai, Tamilnadu, India

*Corresponding author: Dhasarathi Kumar, Department of Public Health, SRM University, Chennai, Tamilnadu, India, Tel: 08807126015; E-mail: dhasarathykumar@gmail.com

Received date: May 21, 2018; Accepted date: June 13, 2018; Published date: June 20, 2018

Copyright: ( 2018 Kumar D. This is an open-access article distributed under the terms of the Creative Commons Attribution License, which permits unrestricted use, distribution, and reproduction in any medium, provided the original author and source are credited.

\section{Short Communication}

According to WHO, the Out-of-pocket Expenditure/payments (OOPs) is defined as the direct expenditures which are made through individuals for their health care when they utilize the services. This Out of Pocket payment is excluded any payment which is paid previously for the health services like health insurance, Out of pocket payments is one of the parts in health care financing landscape, in all countries the health financing is relay on co-payment to mobilize the revenue, user fees, utilizing the health services, includes improves healthcare system efficiency and quality of the services or health system cost [1]. When family spend $10 \%$ or more than $10 \%$ of the total family income which is considered as an indication of catastrophic health expenditure [2].

Increasing catastrophic health expenditure among households may lead to the financial risk and financial insecurity. Country like India though some of the health services were free in public health centres like emergency care, maternal and child health care, Provision of medical care and Immunization \& education to the community, there were charges for services like medicine, bed, user fees and bribe. World health organization define that whenever healthcare expenditure is equal to $40 \%$ or more than $40 \%$ of the total household income then the condition called Catastrophic health expenditure [2]. In simple word, Catastrophic Health Expenditure (CHE) is when family spent a large amount of family income on the health care services, which may end up in poverty as a result [3-9]. The contribution factors of catastrophic Health Expenditure are availing traditional medicine services, hospitalization, Receiving the dentistry services, Drugs, medical diagnostic tests, health-care products, type of medical or surgical treatment availing and lacking in health insurance coverage and this out of pocket expenditure may end up in poverty $[10,11]$. One of the core objectives of universal health coverage (UHC) is financial protection of the population [12].

The accessibility of health care services for poor has improved slightly and the number of the family facing catastrophic health expenditures has seemingly increased among households due to catastrophic expenditure because of this expenditure some family may end up in poverty and financial crises. In country like India though the some of the health services were free in public health centers like emergency care, maternal and child health care, Provision of medical care and Immunization \& education to the community, there were charges for services like medicine, bed, user fees and bribe $[13,14]$. In 50 developing countries the WHO has performed the World Health Survey by using a consistent instrument, between 2002 and 2004 and it contain one single question followed by eight question which is listed below and from these question we can able to find the health expenditure approximately [15]. This survey contains questions regarding the individual household expenditure details on health care services; it will collect the information regarding availing the outpatient services, traditional medication services, dental services, hospitalization of family member, medical/diagnostic investigations, healthcare products and other services which includes food and transportations [16]. The health expenditure approximations can be derived from either the single-item or eight-item questions. Another type of question concerns about the inpatient costs in the past 11 months (exclusion of most recent month) [16,17]. The rural household of an India faces the more Catastrophic Health Expenditure than the urban (rural (25.3\%) and urban (17.5\%)) [9] because of the out of pocket expenditure $87 \%$ rural poverty occurs mainly in the poor states of India and in richest states proposition of poverty in a rural is $67 \%$ [18]. Always the percentage of the poverty is very high in rural areas (3.5\%) than the urban areas $(2.5 \%)[19,20]$. The elementary part of a healthcare system is not only to providing and improving the health status of the population, it has to protect the individual household from a financial crises which take place due to the Out of pocket payments [21-24]. People are protected from the catastrophic if country has risk pooling mechanism [20] but most of the middle and low income/ developing countries experience high OOP payments and due to scarcity of risk-sharing mechanisms and at last OOP will end up in poverty [22-28].

According to the National Health Account (NHA) report, the Total Health Expenditure (THE) for India is estimated at Rs. 4,83,259 crores for the year 2014-2015. Total Health Expenditure (THE) Comprise of current and capital expenditures incurred by Government and Private Sources including External/Donor funds. In India 62.6\% households are affected by OOPE (Rs. 3,02,425 crores) during the year of 2014-15.

\section{Indicator is calculated as:}

$\mathrm{OOP}=($ Household OOP Expenditure for health during the past 12 months/Total annual household income x 100 (WHO).

If its $10 \%$ it's an indicator of the catastrophic health expenditure, and if it's equal or more than $40 \%$ which is called the catastrophic health expenditure.

\section{Conclusion}

Because of high medical fees many households not able to use medical services and without getting proper advice from the professional also they tend to take self-medication's which may lead to the drug resistance [29]. We expect to decrease the OOP expenditures and securing family from poverty by using the risk pooling mechanism and by UHC (universal health coverage). People in the middle-income country the out of pocket expenditures are very high, by finding the determinant of OOP expenditures; we can help in achieving the universal access and health system delivery effectively. Healthcare expenditure is very rapidly rising in countries, especially in developing country. $10 \%$ of the GDP (Gross Domestic Product) globally spent on health [30]. Unfortunately, all of this money is not spent correctly. 
There are inadequate resources [31]. Sustainable development goals are help to eliminate poverty, improving the healthcare \& healthcare system, reduce inequality and economic growth this goal has indirectly decrease the Out of pocket expenditure/ catastrophic health expenditure [32,33].

\section{Acknowledgment}

Many thanks to Dr. Alex Joseph, Prof. Bhagavandas and Dr. Arulmani T for insights and discussions.

\section{References}

1. http://www.who.int/health_financing/topics/financial-protection/out-ofpocket-payments/en/

2. WHO-Health financing for universal coverage (2010) Out-of-pocket payments, user fees and catastrophic expenditure.

3. Steven Buigut RE (2015) Catastrophic health expenditure and its determinants in Kenya slum communities. Intern J Equity Health pp 1-12.

4. Murray MD (2003) Household catastrophic health expenditure: A Multicountry analysis. MEDLINE.

5. Timothy (2007) Protecting households from catastrophic health Spending. Health Systems and Policy Res.

6. Wagstaff A (2003) Catastrophe and impoverishment in paying for health care: with applications to Vietnam 1993-1998.

7. Christopher JL, Murray KX (2003) Assessing the Distribution of Household Financial Contributions to the Health System: Concepts and Empirical Application. Lancet pp: 1-5.

8. World health Organization (2003) The world health report 2003 - shaping the future.

9. van Doorslaer E (2006) Effect of payments for health care on poverty estimates in 11 countries in Asia: an analysis of household survey data. Lancet, summary.

10. Tin Tin Su BK (2006) Catastrophic household expenditure for health care in a low income society: A study from Nouna District, Burkina Faso. pp: 1-6.

11. Chunling Lu (2018) Limitations of methods for measuring out-of-pocket and catastrophic private health expenditures.

12. Organization WH. Health Financing, Financial protection. Geneva: WHO.

13. Almualm SE (2017) Catastrophic Health Expenditure among Developing Countries. Health Systems Policy Res pp: 1-4.

14. Xu K, Evans DB, Kadama P, Nabyonga J, Ogwal PO, et al. (2006) Understanding the impact of eliminating user fees: Utilization and Catastrophic health expenditure in Uganda. Soc Sci Med 62: 866-876.
15. Sengupta A (2005) The private health sector in India, Is burgeoning, but at the cost of public health care. BMJ 331: 1-2

16. WHO (2005) WHO World Health Survey.

17. Chunling Lu (2009) Limitations of methods for measuring out-of-pocket and catastrophic private health expenditures. Medline, Bull World Health Organ pp: 238-242.

18. WHO (2011) World Health Survey, Website, Geneva: WHO.

19. George Gotsadze AZ (2009) Household catastrophic health expenditure: Evidence from Georgia and its policy implications. BMC Health Services Res 9: 69.

20. Garg CKA (2005) Reducing out-of-pocket expenditures to reduce income poverty - evidence from India. World Health Organization, Geneva 2-8.

21. Garg CC (2008) Reducing out-of-pocket expenditures to reduce poverty: a disaggregated analysisat rural-urban and state level in India. Published by Oxford University Press in association with The London School of Hygiene and Tropical Medicine 1-7.

22. WHO (2000) The World Health Report, Health system: Improving Performance. WHO: 8-17.

23. Balarajan YSS (2011) India: Towards Universal Health Coverage for Health care and equity in India. Lancet.

24. Bredenkamp CMM (2011) Catastrophic and impoverishing effects of health expenditure: new evidence from the Western Balkans. Health Policy Plan. Oxford Academic 2-18.

25. Rahman M (2013) Health-Related Financial Catastrophe, Inequality and Chronic Illness in Bangladesh. Plot(s) J 1-6.

26. Shahrawat R (2012) Insured yet vulnerable_out-of-pocket payments and India's poor _ Health Policy and Planning. Health Policy System Res pp: 2-26.

27. Binnendijk E, Koren R, Dror DM (2012) Hardship financing of healthcare among rural poor in Orissa, India. BMC Health Services Res pp: 1-12.

28. Thuan NT (2006) Household out of- pocket payments for illness: evidence from Vietnam. BMC Public Health 1-7.

29. Mylena Aguilar K (2006) Understanding the impact of eliminating user fees: Utilization and catastrophic health expenditures in Uganda. Elsevier.

30. Tenkorang DCA (2006) Mobilizing resources for health: the case for user fees revisited. Center for International Development at Harvard University.

31. WHO (2015) Health systems financing/Global Health Observatory (GHO) data.

32. Joudaki H (2015) Improving Fraud and Abuse Detection in General Physician Claims: A Data Mining Study. IJHPM pp: 165-168.

33. UNDP (2017) Sustainable Development Goal. United Nations Development Programme. 